\title{
Anna Anguissola \\ Ethical Matters: Pliny the Elder on Material Deception
}

\begin{abstract}
This contribution highlights the intellectual dimension of the Roman discourse on materials by discussing the ideological and moral implications of a set of passages from Pliny's Naturalis historia dedicated to golden surfaces. In these passages, Pliny explores the ethical implications of golden veneers in interior decoration as well as in the production of vessels and statues both in bronze and in marble. Throughout the encyclopaedia, gold is presented as the foremost 'problematic' substance due to the conflict between its intrinsic, natural qualities and its economic value. By highlighting the inconsistencies in human appreciation of gold, Pliny exploits the potential of materiality to develop his view of the contemporary society, as well as of the Roman political past and present. In particular, Pliny addresses the issue of gilding and, in general, the practice of disguising the material layers of an object in light of his views about memory and technological progress.
\end{abstract}

The study of decorative systems, defined as environments in which individual elements (such as floors, walls, furniture, sculpture, tableware, etc.) coexist and interact according to prevailing, time-specific principles, requires consideration of the intellectual dimensions of ancient discourses about materials and, especially, the disentanglement of their aesthetic and moral implications. For

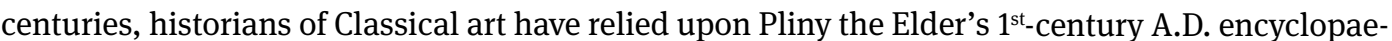
dia as the foundational text of their discipline. In the dense chapters dedicated to the figural arts, which are clustered mainly in the final five books, Pliny introduces crafts, individual artists and artworks according to the raw natural materials each one utilises. Yet Pliny's interest in the physical and symbolic qualities of materials has so far remained relatively neglected in the scholarly literature, which mostly reflects a centuries-old tradition of reading the Naturalis historia as a collection of excerpts about legendary masterpieces and the lives of their makers ${ }^{1}$. Only in recent years have scholars highlighted Pliny's political perspective and begun to understand his statements and narratives about the visual arts as part of a broader discourse on the merits of his Flavian patrons, and of Roman imperialism ${ }^{2}$. While these approaches have greatly advanced our knowledge of Pliny's subject matter and cultural environment, they nonetheless elude questions about the significance of the encyclopaedia's organising criteria and about its engagement with the physical and sensual qualities of artistic materials.

This contribution argues that by considering the ways in which substances and artistic processes are constructed in the Naturalis historia, the material and performative aspects of artistic creation emerge not only as essential preoccupations in Pliny's treatise, but also as important tools to construct and explain the author's view of Rome's history and society. Nowhere does Pliny explore this line of thought as consistently as he does in discussing the uses, meaning and value of gold. In the Naturalis historia, gold occupies an ambivalent position as the chief unit for measuring the price of all natural and artificial goods, while also being the unsurpassed cause of greed (avaritia) and an instrument for extravagance (luxuria). In particular, it is through the relationship between gold

1 The bibliography provided in this article makes no attempt to be comprehensive, but rather acknowledges the works to which I have resorted directly for specific arguments or information. Aude Doody provides an excellent account of the extensive scholarly literature on the life and work of Pliny the Elder in a dedicated Oxford Bibliography (https://doi. org/10.1093/OBO/9780195389661-0194, October $26^{\text {th }}$ 2020). The indisputable relevance of the anecdotes about artists and artworks within the Naturalis historia, which has its roots in the Hellenistic tradition of a discourse about the visual arts constructed as a sequence of increasingly naturalistic achievements, emerges from recent investigations into the topic. See, for instance, Rouveret 1996; Naas 2012; Darab 2014; 2014 ; Platt 2016.

2 Most notably, see Naas 2002; Carey 2003; Murphy 2004.

D Open Access. (C) 2022 Anna Anguissola, published by De Gruyter. (c))BY-NC-ND This work is licensed under the Creative Commons Attribution-NonCommercial-NoDerivatives 4.0 International License.

https://doi.org/10.1515/9783110764734-003 
and other materials - painted plaster, other metals and stone - that Pliny articulates his ethical standpoint, characterising both broader social behaviours and historical individuals in terms of their taste for different substances. I argue that the ethical problem involved in the association of gold with other materials is twofold. On the one hand, economic and aesthetic considerations seem to conflict in Pliny's account of gold, the appreciation of which mainly relies on its price. More modest materials, escaping the trappings of greed, may reflect the artists' creative and cognitive processes more expediently. On the other hand, the taste for disguising less expensive substances under a layer of gold is at odds with both traditional practices and the deference, intrinsic to Pliny's Stoic attitude, towards the unadulterated work of Nature ${ }^{3}$. By investigating Pliny's view on the use of gold in interior decoration, sculpture and gold smithery, I examine the place of artistic materials within the Naturalis historia's literary, moral and epistemological fabric.

\section{Gold and Gilding: Value and Deception}

The concerns that I have raised about the Naturalis historia's internal hierarchies hinge upon issues of how we understand Pliny's criteria for classifying artists, artworks and their display contexts. Indeed, Pliny's presentation follows a desultory logic, which traces intertwining ethical, political, historical and economical lines of reasoning ${ }^{4}$. In a 37-volume compendium of the natural world, which relies throughout on the notions of auctoritas, dignitas, gratia, gloria and nobilitas for assessing individual objects, we would expect to find an eloquent account of these concepts, as applied to artworks, artists, techniques and materials 5 . Yet Pliny provides neither an explicit nor coherent description of these elusive qualities and their implications.

Running throughout the encyclopaedia are implicit tensions between the factors that determine an artwork's authority: the intrinsic worth of materials, which is based on features including colour and reflectivity, texture, hardness or malleability, brittleness or durability, and the extrinsic qualities, such as monetary value, historical circumstances, utility or artistic merit. While the account of gems and precious stones in Book 37 relies largely on the evaluation of natural characteristics, in the chapters dedicated to metals, pigments and sculptural stones (Books 33 through 36), Pliny emphasises accessory features ${ }^{6}$. The itemisation of natural characteristics, thus, seems to provide a device for counterbalancing the paucity of other, easier-to-grasp categories, since Pliny could not resort to the taxonomy provided by modern petrography and crystallography. Instead, in the remainder of the treatise the various external factors that account for auctoritas provide Pliny with a loose conceptual framework for encapsulating his protean subject. Indeed, Pliny relies heavily on instances of extravagant pricing to organise a hierarchy of artworks, and to help arrange his

3 The word Nature is capitalised here to convey the sense of the natural world in the context of Pliny's work, as opposed to our own modern conception of 'nature'.

4 The hierarchies of substances in Pliny the Elder’s Naturalis historia are addressed in Anguissola - Grüner 2020.

5 On the concept of auctoritas in Roman discourses on the figural arts, see Robert 1995. An insightful discussion of auctoritas in the thought and work of Cicero is found in Goodwin 2001.

6 Pliny makes the exceptional status of gems unequivocal. The section opens with a statement that sets these stones apart in the economics of artistic materials (Plin. HN 37, 1). Alone among all substances, gems are so highly regarded on the basis of their visible and intrinsic qualities (varietas, color, materia, decor) that it is sometimes considered inappropriate - almost sacrilegious (nefas) - to carve them (the concept of the untouchability of Nature's perfect products returns in Plin. HN 37, 28, regarding rock crystal). Required to classify hundreds of precious and semi-precious stones based on optical and physical qualities alone, Pliny grounds his scale of value on three main surface features: transparency, clarity and brilliance. Nouns such as nitor, splendor and fulgor, verbs like tralucere, translucere, nitere, fulgere, refulgere, radiare, exardescere, repercutere and other compounds like allucere, perlucere, collucere and relucere crowd the text. The elaborate description of emeralds is exemplary of Pliny's challenges and of his approach to the description of gemstones and their auctoritas (Plin. HN 37, 62-64). The concept of color as a means of assessing the quality of a gem is explored by Bradley (2009, 101-106). 
subject historically ${ }^{7}$. Nonetheless, he cannot fail to find the evaluation of art based on commercial desirability to be at odds with his Stoic outlook ${ }^{8}$. This antagonistic dimension between competing concerns is occasionally made explicit, as Pliny decries the increasingly prominent interest in economic value as responsible for the degradation of art's position within society, that is, the degradation of its authority (cum ad infinitum operum pretia creverint, auctoritas artis extincta est) . $^{9}$

Unsurprisingly, Pliny comes closest to actually discussing the relationship between natural qualities and monetary value in the passage where he also discusses the provenance, methods of extraction, technologies and uses of gold ${ }^{10}$. Being the standard of value for all other materials, gold holds a special place in Pliny's construction ${ }^{11}$. He explains that the chief popularity (gratia) of this substance (materia) has been won not by its colour (color), that of silver being brighter (clarior) and more like daylight (magisque diei similis). Along the same line of reasoning, 'nor is it its weight (pondus) or its malleability (facilitas) that has led to it being preferred to all the rest of the metals (praelatum est ceteris metallis), since in both qualities it yields the first place to lead'. The position of gold in the hierarchies of materials (causa pretii maior) depends on the consideration that 'gold is the only thing that loses no substance by the action of fire (nihil igne deperit)' and that 'it gets extremely little worn by use (quod minimi usus deterit)'. The decisive natural property of gold is its durability. This is a treacherous concept in itself, since it pertains in turn to the quality of retaining shape, as well as to its associated economic value. The boundary between intrinsic and extrinsic value is, for this reason, particularly unstable in the case of gold. What really matters about the qualities of this metal is their reliability (and thus, the stability of its economic value) rather than their relative superiority as compared to other substances.

A further and subtler layer of criticism applies to the practice of gilding, i.e., concealing other substances under a thin layer of gold ${ }^{12}$. In Pliny's view, gilding falls under the category of 'compounds', which constitutes an inherently questionable material classification ${ }^{13}$. The production of a compound is in itself considered to be an extravagant display of luxury, since it entails the manipulation of the products of Nature, which are in themselves perfect. The ideological dimension of such an antithesis between (deceptive) ars and (genuine) natura is apparent in the types and uses of wood. In this field, extravagance takes the form of a reprehensible taste for veneer; that is, the deceitful act of 'making an outside skin for a cheaper wood out of a more expensive one' ${ }^{\text {'4 }}$. Not unexpectedly, artificial concoctions that undermined the natural relationship between materials and value allegedly had their heyday during the rule of Nero, who, as I will argue in the following

7 On the relationship between auctoritas and price in the Naturalis historia, see esp. Papini 2020.

8 Pliny's criticism of luxury targets in particular the private enjoyment of artworks and eccentric furnishings. For his criticism of greed and extravagance (avaritia and luxuria) and its roots in Flavian political culture, see Wallace-Hadrill 1990, 85-92; Isager 1991, 52-55. 70-73; Carey 2003, 76-79; Cotta Ramosino 2004, 251-270; Naas 2006. For Pliny’s place in Roman moralising discourse, see Citroni Marchetti 1991.

9 Plin. HN 34, 5.

10 Plin. HN 33, 58-60.

11 See Dauzat in Dauzat - Zehnacker 1999, $169 \mathrm{f}$.

12 The literature on gilding in ancient bronze and marble sculpture is presented and discussed in Faedo 2020. For an individual case study about the semantics of gilding in Late Hellenistic marble sculpture (the Delos Diadoumenos at Athens, National Archaeological Museum), see Anguissola 2019.

13 The criticism of compounds is clear in Plin. HN 9, 139; 13, 1. 17f.; 14, 2f.; 22, 118; 24, 4f.; 29, 24f.; 33, 49. Pliny comments negatively about the practice of dipping cloth in two different shades of purple dye (a luxuria duplex), as well as the expensive and elaborate metal alloys used in his times (Plin. HN 9, 139: adulterare adulteria naturae): see Citroni Marchetti 2011, 181. Perfumes are presented as objectionable compounds of natural odours (Plin. HN 13, 1. 17 f.). This criticism culminates in the passages devoted to medical drugs, overingenious compounds that relied heavily on expensive ingredients imported from the east and from India (Plin. HN 22, 118; 24, $4 \mathrm{f}$.). The best-known instance of this interest in unnatural compounds is Mithridates' theriake, with its 54 ingredients (Plin. HN 29, $24 \mathrm{f} .:$ excogitata compositio luxuriae). For Pliny's passages on eastern perfumes and the Mithridates anecdote, see Beagon $1992,228 \mathrm{f}$; Jones-Lewis 2012, esp. 61-66.

14 Plin. HN 16, $232 \mathrm{f}$. 
sections, Pliny depicts as the pivotal example for the 'improper' use of materials. According to Pliny, at that time the taste for counterfeits even extended to the manufacture of wooden panels out of tortoiseshell - an egregious feat of deception. A rare and costly material (the shell of tortoises) was painted so as to lose any semblance of its authentic self (ut pigmentis perderet se), thereby imitating the ordinariness of wood, and embracing strategies of illusion that were both visual and intellectual. Wood, which had come to be seen as second-rate owing to its availability, was back in vogue as a fabrication (modo luxuria non fuerat contenta ligno, iam lignum et e testudine facit).

These comments highlight a consistent preoccupation with material integrity in the Naturalis historia, one that appears to only be explicitly discussed in the encyclopaedia's last book. This book is dedicated to gemstones, exceptional items able to provide 'a supreme and perfect aesthetic experience of the wonders of Nature' ${ }^{15}$. As the perfect product of Nature, gems and other rare stones such as rock crystal defy the bounds and preoccupations of human economy, and do not require engraving or other human intervention to enhance their value ${ }^{16}$. Among the primary concerns pervading Pliny's narrative is the delicate balance between acknowledging Nature's (inviolable) perfection, and the recognition of human ingenuity. In a broader perspective, the negative comments on corrupting substances (such as gold) and on deceptive 'unnatural' practices (such as gilding) are rooted in Pliny's wholesale denunciation of what he perceives to be the moral decline of his time. Importantly, the effects of this decline become apparent above all in the perverse evaluation and use of artistic materials. Since gold was used to determine the commercial value of other materials, the taste for it expresses aesthetic choices that privilege financial concerns over artistic merit. As a consequence, the technique of disguising other materials with gold determines the subversion of natural hierarchies and affects the correct evaluation of both natural properties and legitimate artistic skill.

\section{Gilded Walls: The Aesthetics of Ambiguity}

In a well-known passage from Book 35, which most scholars have regarded simplistically as yet another example of Pliny's grievances regarding the moral deficiencies of his epoch, Pliny interprets the emergence of gold in interior decoration as the culmination of a progression towards increasingly deceptive practices ${ }^{17}$. In the opening paragraphs of his book on pigments, Pliny bemoans the decline of painting, castigating the coarsening taste of his contemporaries, who seem to be less interested in figural painting than they are in marble veneers, to the point that they even cover the latter in gold ${ }^{18}$. Painting (pictura) is said to have once been illustrious (arte quondam nobili) at the time 'when it ennobled others whom it deigned to transmit to posterity' (et alios nobilitante, quos esset dignata posteris tradere). On the contrary, in Pliny's world it 'has been entirely ousted by marbles, and indeed finally also by gold' (nunc vero in totum marmoribus pulsa, iam quidem et auro). These two materials have come to cover the entire wall, leaving little or no space for the formerly acclaimed, earnest art of plasterwork.

A passage on metals from Book 33 clarifies that Pliny's objection is not aimed at the practice of gilding in itself, but at certain contexts and associations of its employment (although he is wellaware of this distinction's thorny nature) ${ }^{19}$. Here, Pliny describes a transition in the application of this technique from the public (sacred) to the private sphere, detailing gilding's stages of the introduction into the Roman world: from the roofs of temples to the ceilings (laquearia), vaults

15 Plin. HN 37, 1.

16 Plin. HN 37, 1. 26. 28.

17 Plin. HN 35, 2 f.

18 For archaeological commentaries on this passage, see Croisille 1985, 132-134 and Corso in Conte 1988, 293. 295. 297.

19 Plin. HN 33, 57. 
(in camaras) and walls (parietes) of houses (in privatis domibus) ${ }^{20}$. This shift in decorative fashion mirrors the progression described in the opening paragraphs of Book 35 and is linked to an opulent 'aesthetic of ambiguity'. According to Pliny, this revolution of taste in interior decoration began with the introduction of marble crustae on walls, which subverted the relationship between natural landscapes and artificial indoor spaces (spatia montes in cubiculo dilatantia) ${ }^{21}$, then moved towards deceptive strategies such as the use of golden veneers, before finally culminating in the imitation of painted images by means of stone inlays (lapide pingere) ${ }^{22}$. Using gold leaf to conceal marble implies a double layer of fabrication: modest plaster is hidden beneath slabs of lavish marble, which are in turn disguised by gold. The same concept applies to the creation of 'painted images' by means of marble, which simulate the visual effects of pictures with more expensive materials and a radically different technique. Pliny again identifies this change in decorative taste as emerging immediately before and during the reign of Nero, and thereby connects, in a chain of effects and their causes, certain elements of decor with particular ethical approaches and preoccupations, as well as with Rome's political landscape.

The criticism of golden surfaces in interior decoration is rooted in a broader discourse regarding the semantics of materials as components connected with social behaviour, and is especially clear when we compare the passages examined thus far with others that discuss solutions from the religious sphere and the distant past. When describing the interior of a shrine at Cyzicus ${ }^{23}$, for instance, Pliny praises the insertion of thin gold threads into the vertical joints of the stonework. This technique created spectacular visual effects by allowing fine filaments of light to shine through the interstices, providing a warm, gentle reflection that danced upon the surface of the cult statues (lenique adflatu simulacra refovent) ${ }^{24}$.

Significantly, the architect who devised this method and the sculptor who dedicated an ivory statue of Jupiter and a marble Apollo within the shrine were, in fact, the same person. The result was a Gesamtkunstwerk that broadcast its maker's ingenuity (ingenium) through the use of prestigious materials (materia) such as gold, precisely because the latter remained cleverly concealed. The

20 Cf. Vitruvius' famous discussion (Vitr. De arch. 7, 5) on the appropriateness of wall decoration relating to the reasonable choice of subjects and consistency with the function of a given space. While Pliny makes a clear distinction between usus and luxuria, allowing for the use of certain materials due to their natural properties (as is the case for marble columns in temple architecture, which are employed for higher stability: see Plin. HN 36, 45), he is aware that the introduction of new technologies in the public sphere had often been a cover for private exploitation (Plin. HN 36, 5f.). In Plin. HN 37, 18, he details a similar trajectory for myrrhine vases, introduced to Rome as war booty and sacred dedications before passing into private use (quae protinus ad hominum usum transiere).

21 It is no surprise that in referring to the domestic sphere, the cubiculum (a bedchamber, the most private space in the Roman house) is used as a pars pro toto. The reference to a cubiculum in a negative sense - as a space for selfish indulgence, in contrast with the openness of the city - is central to the passage (see infra) about Tiberius' removal of the Apoxyomenos from public view. It returns in a passage (Plin. HN 35, 70) about a painting by Parrhasius that Tiberius loved (amavit) to the point that he locked it (inclusit) in his bedchamber. When describing Nero's misuse of art in his Domus Aurea and his equally predatory disposition towards it, Pliny employs the word sellarium or 'private parlour' instead, highlighting the subversively disproportionate size of Nero's abode (Plin. HN 34, 84; 36, 11). The term sellarium does not occur anywhere else in the Naturalis historia. Significantly, it appears in Suetonius' 'Life of Tiberius' (Suet. Tib. 43) regarding the rooms in the emperor's villa at Capri that were designed for sexual encounters and the enjoyment of erotic paintings and statues.

22 In Plin. HN 22, 4, Pliny reiterates his preference for walls adorned with vegetable pigments (herbis tingui parietes) over those painted 'with stone' (pingi lapide). In fact, the development of mosaics seems to follow a similar 'topographic' transition, from the floor of a sanctuary to the ceilings of (presumably private) buildings (Plin. HN 36, 189).

23 Plin. HN 36, 98.

24 Although the account of this temple at Cyzicus depends upon sources whose reliability is hard to judge, Pliny must have had direct experience of a building in Rome that evoked similar impressions (Plin. HN 36, 163). During Nero's principate, Pliny informs us that a new type of hard, white and translucent (lapis duritia marmoris, candidus atque translucens) stone was discovered in Cappadocia. This material was used to rebuild a temple of Fortuna - an older temple originally consecrated by Servius Tullius and later incorporated (i. e., appropriated) by the emperor into his Golden House (amplexus aurea domo). On this temple, see Corso in Conte 1988, 701. 
success of this project rests on the choice to exploit the physical properties of gold alone - colour, brilliance, and malleability (returning to the vocabulary employed by Pliny, its color, fulgor and facilitas $^{25}$ ) - instead of highlighting its monetary value. As is to be expected, the paradigm for the 'correct' use of natural materials refers specifically to the sphere of cult practice, and to venerable antiquity, as opposed to nefarious contemporary use within the private domain.

\section{Gilded Vessels: An Anonymous Art}

At the beginning of Book 35, Pliny expands his discussion of gilded walls by making a similar point with regard to metalwork ${ }^{26}$, comparing the former with the engraved bronze shields (aerei ponuntur clipei) covered in silver (argentea facie) that were set up in public locations ${ }^{27}$. Here, too, a relatively modest substance (bronze) is disguised underneath a material layer that is more appealing from a commercial standpoint (silver). Both the purchasers and viewers were apparently indifferent to the 'rough characterisation of the figures' (surdo figurarum discrimine) ${ }^{28}$ on these shields, demonstrating that the display of material (materiam conspici) alone was valued over artisanal expertise and finesse ${ }^{29}$. This point is made explicit in the case of silver vessels plated or inlaid with gold ${ }^{30}$. According to Pliny's ideologically partisan account, this disingenuous practice was so popular in his day that gilded pieces had come to garner a higher price than those cast in solid gold (pluris veneunt inaurata quam aurea) - a subversion that parallels the extravagant practice of painting rare and costly tortoiseshell to imitate easily available and humble wood, as described above.

Technical skill (ars) and ingenuity (ingenium) are arguably the most ambiguous categories in Pliny's account of the figural arts. Indeed, the relationship between material and craftsmanship is rarely straightforward in the Naturalis historia, rooted as it is in an ambivalent ethical and intellectual programme. On the one hand, technological advancements mirror the glory of Rome under Pliny's Flavian patrons. The introduction of hitherto unknown or unattainable goods and new technologies was made possible by the almost boundless expansion of the empire. On the other hand, innovation and the availability of resources might threaten the survival of Rome's venerable traditions. From this perspective, gold is presented as a 'problematic' substance and likewise gilding as a 'problematic' technique. The new style of interior decoration with its layers of marble and gold, which Pliny criticises in the opening of his book on pigments, is claimed to be detrimental to the art of painting, once a propitious vehicle for craftsmen looking to attain durable celebrity. Both gold as a material and gilding as a practice pose an insurmountable obstacle to the display of ars and ingenium, and thus to achieving fame as a craftsman.

25 Plin. HN 33, 58.

26 Plin. HN 33, 57: iam et ipsi tamquam vasa inaurantur.

27 Plin. HN 35, 4.

28 Harris Rackham translates this passage as 'with only a faint difference between the figures'; see also Croisille: 'la distinction entre les traits individuels est ignorée’ (Croisille 1985); Mugellesi in Conte 1988: ‘senza alcuna sensibilità nel differenziare le figure'. In a forthcoming paper, Lucia Faedo explores the problems that gilding - and in general overlapping layers of different materials - pose to experiencing and understanding the formal characters (e. g., surface treatment, contours, quality of carving) of both bronze and marble statues. On the issues regarding vision and the senses in the perception of bronze and stone artworks, see Anguissola - Faedo, forthcoming.

29 In Plin. HN 34, 5, Pliny one again explores this concept with reference to bronze sculpture. He explains that technique (ars) was once held in higher esteem (pretiosor) than the substance (materia), notwithstanding the fact that copper used to be blended with gold and silver; but in his times, cum ad infinitum operum pretia creverint, auctoritas artis extincta est. The main point in this discussion, which provides one premise for the presentation of Corinthian bronze, is that now not even chance (fortuna) is able to produce fine artworks in bronze, such is the pre-eminence of matter and its monetary value over any concern about craftsmanship.

30 Plin. HN 33, 49. 
Implicitly, then, and in contrast to painting, the new fashion for covering walls and metal surfaces with more costly materials required less skill on the part of its practitioners than if less expensive materials and traditional methods had been used. The same contrast emerges between the two most precious metals, gold and silver. Such is the appetite for gold, in Pliny's narrative, that fervour towards the bare material has overtaken any admiration for the technical skill involved in its associated craft. Indeed, Pliny purports that it has become virtually impossible to achieve fame as an engraver of gold. The opposite is true for silver, which was the material of choice for many excellent craftsmen ${ }^{31}$. Pliny sees the artistic landscape of his time as defined by the loss of craft and technical knowledge; a loss that gives way to an 'anonymous art' that variously neglects names, artists and technical expertise. Mnemonic oblivion of artists' names, such as those of the craftsmen who worked with lavish gold rather than engaging in the 'formerly illustrious' art of painting, coincides with forgetfulness about material identities. It is around this same point in Book 36, which focuses on sculptural and building stones, that Pliny is unable to attribute a marble statue of Janus to a specific master, due to the fact that the craftsman's hand (manus) had been masked by a veneer of gold (auro occultatus) ${ }^{32}$. In severing the physical connection between the two original agents of a man-made object (Nature, as the maker of all substances, and the human artisan), the act of veneering is blamed for populating the Roman world with disconnected, 'anonymous' artefacts, objects absent of genealogical relations and therefore considered to be inexplicable.

\section{Gilded Statues: Material Appropriations}

The values and semantics attached to gold are crucial to understanding Pliny's comments on the use of this substance for the purpose of 'enhancing' the monetary value of sculpture. The aesthetics and, more importantly, the ethical challenges of gold emerge in the dense section regarding the $4^{\text {th }}$-century B.C. sculptor Lysippus and his bronze portrait of Alexander as a boy ${ }^{33}$. In Pliny's account, Nero was enamoured with this statue (delectatus admodum illa) and ordered that it be gilded (statuam inaurari iussit), thereby compromising its artistic merit by increasing its monetary value (cum pretio perisset gratia artis) ${ }^{34}$. However, it was the choice to remove the golden layer (likely after the emperor's demise) that actually ended up increasing the value of the statue (pretiosorque talis existimabatur), even if, or rather because, its surface was beset with scars and incisions. In other words, in the case of a centuries-old masterpiece, the addition of an expensive material did little to enhance the work's overall significance, which rather benefitted from the visible traces of its history.

The unfortunate decision to conceal Lysippus' bronze surface under a coat of gold was the result of Nero's infatuation with the piece. One cannot fail to notice the similarities in content and language with the presentation of another statue by Lysippus, his famous Apoxyomenos, which Pliny mentions immediately before the portrait of Alexander puer ${ }^{35}$. Indeed, such was Tiberius's fondness (mire gratum [...] adamatum) for the Apoxyomenos that he had the statue installed in his bedchamber, putting another in the original's place (alio signo substituto) at the Baths of Agrippa

31 Plin. HN 33, 154.

32 Plin. HN 36, 28. On this passage, see Faedo 2020; Anguissola - Faedo, forthcoming.

33 Plin. HN 34, 63.

34 A later Greek source, a discourse by Julian the Apostate (2, 4, 54 B-C) includes a similar anecdote about the marble statue of Eros at Thespiae that was carved by Praxiteles. According to this account, the decision to have its wings


is also one of human avaritia. According to Pausanius (9, 27, 4), after being carried off to Rome by Caligula it was restored to its original location by Claudius and then stolen again by Nero. On the meaning of xápıs/gratia, see Pollitt 1974, 297-301. 380 f.; Moussy 1966, 407-435.

35 Plin. HN 34, 62. 
in the Campus Martius. However, owing to public pressure, the original was eventually returned to its former location. Tiberius, who the Naturalis historia casts in a largely unfavourable light, was unable to resist his capricious passion for the statue ${ }^{36}$. Pliny presents this anecdote as an example of the illegitimate use of art, which in this case was transferred from the domain of collective utility to one man's cubiculum - a private space for total self-indulgence. The appropriation of art and its removal from the public sphere reflects again the prevailing patterns of behaviour in contemporary Roman society, which Pliny depicts as ruled by man's insatiable desire and uncontrolled consumption of natural resources: avaritia and luxuria.

This abuse of art constitutes a leitmotif in Pliny's criticism of historical emperors. Whereas Tiberius is depicted as an insatiable collector, doting on his masterpieces in the impenetrable privacy of his cubiculum, Nero's entire Domus Aurea, which loomed over the city as a menacing border ${ }^{37}$, is presented as a veritable prison for the art of its decorator (carcer eius artis), the Roman painter Famulus ${ }^{38}$. Obviously, Nero's destructive attitude poses a much greater danger to the integrity of a work of art than Tiberius's mere selfishness. While Tiberius' transgressions were limited to the removal of artworks from public spaces, Nero's fervour extended to the point of altering their material identity. Nero patently mistook a work's auctoritas for its pretium (the latter being, at most, a function of the former) and thereby failed to recognise the importance of natural properties and technical skill (ars) in the viewing and understanding of art.

It is not surprising that the reign of Nero allegedly coincides with questionable developments such as the practice of covering interior walls with a double coating of marble and gold. The point in question is a matter of misplaced judgement as much as illegitimate appropriation. Most criticisms of gilded surfaces within the private spaces of personal residences fall within this category. For although the gilding of both inner environments and statues appears to be a permissible practice in the sacred sphere and is, more importantly, traditional ${ }^{39}$, its use as a means for emphasising private ownership and dominion over Nature emerges as a testament to moral corruption.

As several scholars have observed, Nero and Caligula are the figureheads around whom Pliny's narrative of corruption and immorality unfolds, as opposed to the reinstated mores of Flavian Rome $^{40}$. Unsurprisingly, the similarities between Nero and Caligula include both emperors' immoderate appetite for gold ${ }^{41}$. Pliny constructs Nero's character through the progressive misuse of natural substances, from relatively harmless displays of wanton recklessness, to permanent damage that still does not preclude the object's preservation, to final wholesale and irreversible destruction ${ }^{42}$. The Naturalis historia depicts Nero, at the very end of his reign, smashing two precious crystal vessels in a narcissistic fit upon receiving a message that all was lost ('to make it

\footnotetext{
36 Anecdotes about Tiberius' erotic misuse of art seem to have been quite popular and are by no means limited to the Naturalis historia: see, for example, Suet. Tib. 44, 2. For Pliny's comments on Tiberius, see Baldwin 1995, 64-66. 37 Plin. HN 36, 111.

38 Plin. HN 35, 120. The contrast with the ethics of Flavian emperors is apparent in Pliny's narrative (Plin. HN 34, 84) about Vespasian's public restitution of many artworks despoiled by Nero (violentia Neronis in urbem convecta) and held captive in his palace (in sellariis domus aureae disposita). On the Flavian emperors' engagement with the artistic and monumental landscape of Rome, see Baldwin 1995, $59 \mathrm{f}$.

39 Pliny mentions the gilded ceiling of the Temple of Jupiter on Capitoline Hill (Plin. HN 33, 57), and the gilded simulacrum of Fortuna at Praeneste (Plin. HN 33, 61).

40 Pliny's attitude towards earlier Roman emperors is explored by Naas (2002, 98f.); see also Baldwin (1995, 67. 73-75) for his stance on the recent Neronian past. In the book on anthropology and human physiology (Plin. HN 7, 45), Caligula and Nero are dismissed as 'the two firebrands of mankind' (faces generis humani), and Nero again in Plin. HN 7, 46 as an 'enemy of mankind' (hostem generis humani).

41 See Plin. HN 33, 79 on Caligula: avidissimum auri.

42 Nero's destructive attitude finds a parallel in Caligula's act of vandalism against the wall paintings of Helena and Atalanta at Lanuvium (Plin. HN 35, 17 f.), which had ignited his lust (libidine accensus) to such an extent that he attempted to tear them off the wall and remove them from the sanctuary. In this case, Pliny creates an extraordinary story of 'material resistance', as Caligula's attempt is frustrated by the tenacious defiance of the plasterwork itself, which could not be detached from the wall (si tectorii natura permisisset).
} 
impossible for any other man to drink from those cups' $)^{43}$. As mentioned before, the presentation of rock-crystal in the last book of the encyclopaedia revolves around its peculiarity as a supreme, rough product of Nature, one that surpasses the work of any craftsman. Once it is broken, as Pliny remarks in explaining the significance of Nero's transgression, this substance 'cannot be mended by any method whatsoever' (fragmenta sarciri nullo modo queunt).

Returning to the statues by Lysippus that were removed or altered by Tiberius and Nero, it seems important to highlight Pliny's interest in the consequences of these incidents and the role that public opinion played in reversing the emperors' reckless decisions. The statue of Alexander had survived Nero's violation but was forever altered thanks to the removal of the gold layer. However, the marks and scars on its surface, which replaced both the smooth, shiny patina of Lysippus' bronze and the glossy, gilded surface that had formerly adorned it, ended up increasing the artwork's value. Clearly, the performative traces of Nero's offence, and of its removal, added to the statue's significance by rendering it an effective reminder of both imperial abuse and, more broadly, the consequences of the illegitimate use of $\operatorname{art}^{44}$.

After all, it is through this inherent tension between forgetting and reminding - or more precisely, between deleting and reminding - that Pliny considers Nero's monumental and artistic heritage. While the meaning of Nero's most famous gilded artwork (his own colossal statue, displayed in the vestibule of the Domus Aurea) was 'corrected' by reimagining the figure (Vespasian had the statue changed to depict Sol $)^{45}$, in order for the statue of Alexander to be removed from the shade of a disgraced emperor, it was necessary to restore its material identity. In the case of the famous Colossus, a new interpretation of the figure could be provided simply by playing on the statue's original double entendre, which referred to both an emperor and a god. However, in the case of Lysippus' Alexander, reminders of Nero's vandalism and its embodiment of his moral corruption were kept alive by the removal of its materiality and by directing attention to the vestiges of the same. According to visual strategies familiar to the Roman public ${ }^{46}$, the restoration of the statue's bronze surface was not intended to prevent the recollection of Nero's behaviour, but rather served to highlight the conscious return to a moment before his reign, as well as the collective consensus regarding this effort. The piece's value did, in fact, increase following its restoration.

\section{Conclusions}

The unstable, tenuous border between human ingenuity and impudence reflects a conflict that is inherent in Pliny's understanding of political expansion and economic growth ${ }^{47}$. In the Naturalis historia, technological progress as mirrored by the discovery of new substances and the taste for 'inexplicable mixtures' (compositiones et mixturae inexplicabiles) reflects the exceptional availability of resources, the knowledge brought about by Rome's hegemony over a vast empire, and the gradual loss of traditional wisdom, which often involved the use of humbler materials and less

43 Plin. HN 37, 29. A slightly different version of this anecdote appears in Suet. Ner. 47, 1; see Sansone 1993, 187 f. for the sources of this Suetonius passage.

44 I borrow the concept of 'performative traces' from a paper ('Periferie, epitomi, residui: strategie dell'attenzione') delivered by Salvatore Settis at the Kunsthistorisches Institut of Florence, as part of the symposium 'Detail und Aufmerksamkeit' in honour of Alessandro Nova (May 2014).

45 Plin. HN 34, 45. For the colossus of Zenodorus, see Ensoli 2002; 2007, $409 \mathrm{f}$. $416 \mathrm{f}$. On the relationship between gold and Nero's solar imagery, see Bergmann 1994, 5f.; 2013, 342-351.

46 E.g., the widespread practice of reworking the portraits of those emperors who had suffered damnatio memoriae notably Caligula and Nero at that point in time - ultimately played on the same visual strategies of 'visible effacement'. 47 Lao (2011) explores the connections between Pliny's attitude towards luxuria and the economic and retail landscape of his time. Healy (1999), Beagon (1992, 57-68), Isager (1991, 33-42) and Citroni Marchetti (1991, 202-204. 230. 237) all engage with Pliny's ambivalent concept of progress and man's relationship with Nature. 
elaborate techniques ${ }^{48}$. Expansion, based on Pliny's argument, is about oblivion as well as growth. The increasing accessibility of new information and the simultaneous decline of traditional knowledge determined by Rome's expansion ultimately provide the encyclopaedia's raison d'être, which in Pliny's words is about lending 'novelty to what is old, authority to what is new'49. According to this historical perspective, Pliny's task is, first and foremost, to explore the causes and mechanisms for the formation of memory and its erasure.

Within this ideological framework, the problems regarding the visibility and integrity of surfaces occupies a central place. Surfaces can either expose or disguise the material truth of an object and consequently its position within the natural ranking of substances, as well as the correct (albeit artificial) ranking of human skilfulness. In light of these comments, it becomes clear why, according to Pliny, alteration of an artwork's surface (for instance, by means of gilding) also resulted in damage to the gratia artis - it obliterated the unique marks of the artist's skill. The alterations, therefore, testify to incompetent judgement and endanger the viewer's ability to correctly evaluate the work. This proves all the more true when the material that is chosen for the outer layer is gold: gold is a substance that fundamentally lacks natural excellence, and owes its place in the hierarchy of materials to its monetary value alone.

By dismissing the statements about gold scattered through the Naturalis historia as yet another instance of Pliny's conventional moralism, we would fail to recognise the relevance of the discourse on artistic materials and the articulation of crucial ideological and ethical points. The material and performative aspects of creation occupy a central position within the lengthiest and most detailed account of the visual arts passed down to us from classical antiquity. Most importantly, these preoccupations provide Pliny with fundamental means for constructing and explaining his view of Roman history and society, as well as his understanding of the intellectual work and, more specifically, his own strategies as a chronicler and collector of the memorable facts of Nature. Artistic materials (gold), techniques (gilding), the relationship between different substances (gold and plaster, marble, bronze and silver) and the visual effects of entire decorative systems (such as the walls embellished with paint, stone veneers and layers of gold) participate in a broader discussion about collective taste, economy, social dynamics, history and competing moral standards. As is clear in Pliny's account of visual culture, artistic materials provided an efficient symbolic tool for the Romans not only to represent themselves but also (and more subtly) to reflect upon their identity, past and present.



48 Plin. HN 24, 4 f. See also Plin. HN 14, 2f., as well as the comments in Citroni Marchetti 1991, 225 and Murphy 2004, 68-71. Pliny's perspective on Rome's empire and its social, economic and ideological consequences is explored by Laehn (2013).

49 Plin. HN Praef. 15. 


\section{Bibliography}

\section{Primary Sources}

Plin. HN (Latin)

Plinius maior: Naturalis Historiae, Libri XXXVII, vol. I-V, ed. by C. Mayhoff (Leipzig 18751906)

Plin. HN 3-7 (English) Pliny: Natural History, Volume IV, Books 12-16, transl. by H. Rackham (Cambridge, MA 1942)

Plin. HN 8-11 (English) Pliny: Natural History, Volume IV, Books 12-16, transl. by H. Rackham (Cambridge, MA 1940)

Plin. HN 12-16 (English) Pliny: Natural History, Volume IV, Books 12-16, transl. by H. Rackham (Cambridge, MA 1945)

Plin. HN 33-35 (English) Pliny: Natural History, Volume IX, Books 33-35, transl. by H. Rackham (Cambridge, MA 1952)

Plin. HN 36-37 (English) Pliny: Natural History, Volume X, Books 36-37, transl. by D. E. Eichholz (Cambridge, MA

1962)

Plin. HN 35 (French) Pline l'Ancien, Histoire Naturelle. Livre XXXV, ed., transl. and commentary by J.-M. Croisille (Paris 1985)

\section{Secondary Literature}

Anguissola 2019: A. Anguissola, Ergon e parergon. Osservazioni su attributi e sostegni nella serie copistica del Diadumeno, Mare Internum 11, 2019, 25-42

Anguissola - Faedo, forthcoming: A. Anguissola - L. Faedo, Lo sguardo di Plinio tra tecnica e materia. Le statue e la loro superficie, in: M. Collareta - M. Ferretti - S. Maffei - C. M. Sicca (eds.), Le parole del marmo. Lessico diacronico della scultura e saperi tecnici tra passato e presente (Pisa forthcoming)

Anguissola - Grüner 2020: A. Anguissola - A. Grüner (eds.), The Nature of Art. Pliny the Elder on Materials (Turnhout 2020)

Baldwin 1995: B. Baldwin, Roman Emperors in the Elder Pliny, Scholia 4, 1995, 56-78

Beagon 1992: M. Beagon, Roman Nature. The Thought of Pliny the Elder (Oxford 1992)

Bergmann 1994: M. Bergmann, Der Koloß Neros, die Domus Aurea und der Mentalitätswandel im Rom der frühen Kaiserzeit (Mainz 1994)

Bergmann 2013: M. Bergmann, Portraits of an Emperor. Nero, the Sun, and Roman Otium, in: E. Buckley - M. T. Dinter (eds.), A Companion to the Neronian Age (Chichester 2013) 332-362

Bradley 2009: M. Bradley, Colour and Meaning in Ancient Rome (Cambridge 2009)

Carey 2003: S. Carey, Pliny's Catalogue of Culture. Art and Empire in the Natural History (Oxford 2003)

Citroni Marchetti 1991: S. Citroni Marchetti, Plinio il Vecchio e la tradizione del moralismo romano (Pisa 1991)

Citroni Marchetti 2011: S. Citroni Marchetti, La scienza della natura per un intellettuale romano. Studi su Plinio il Vecchio (Pisa 2011)

Conte 1988: G. B. Conte (ed.), Gaio Plinio Secondo. Storia Naturale V, transl. and notes by A. Corso, R. Mugellesi, and G. Rosati (Turin 1988)

Cotta Ramosino 2004: L. Cotta Ramosino, Plinio il Vecchio e la tradizione storica di Roma nella Naturalis Historia (Alessandria 2004)

Darab 2014: Á. Darab, Natura, Ars, Historia. Anecdotic History of Art in Pliny the Elder's Naturalis Historia I, Hermes 142, 2, 2014, 206-224

Darab 2014a: Á. Darab, Natura, Ars, Historia. Anecdotic History of Art in Pliny the Elder's Naturalis Historia II, Hermes 142, 3, 2014, 279-297

Dauzat - Zehnacker 1999: P.-E. Dauzat - H. Zehnacker (eds.), Pline l’Ancien, Historie Naturelle. Livre XXXIII, transl. by H. Zehnacker, introduction and notes by P.-E. Dauzat (Paris 1999)

Ensoli 2002: S. Ensoli, Una nuova ipotesi sul Colosso di Nerone. A proposito dei tre frammenti bronzei dei Musei Capitolini, in: J.-M. Croisille - Y. Perrin (eds.), Neronia VI. Rome à l'époque néronienne (Brussels 2002) 97-122

Ensoli 2007: S. Ensoli, Il Colosso di Nerone-Sol a Roma. Una 'falsa' imitazione del Colosso di Helios a Rodi. A proposito della testimonianza di Plinio, della ricostruzione del basamento nella valle del Colosseo e dei 'tondi adrianei', in: Y. Perrin (ed.), Neronia VII. Rome, l'Italie et la Grèce. Hellénisme et philhellénisme au premier siècle ap. J.-C. (Brussels 2007) 406-427

Faedo 2020: L. Faedo, Gilding. Art and Technique, Vision and Morals, in: A. Anguissola - A. Grüner (eds.), The Nature of Art. Pliny the Elder on Materials (Turnhout 2020) 224-235

Goodwin 2001: J. Goodwin, Cicero's Authority, Philosophy \& Rhetoric 34, 2001, 38-60

Healy 1999: J. F. Healy, Pliny the Elder on Science and Technology (Oxford 1999)

Isager 1991: J. Isager, Pliny on Art and Society (Odense 1991)

Jones-Lewis 2012: M. A. Jones-Lewis, Poison. Nature's Argument for the Roman Empire in Pliny the Elder's Naturalis Historia, Classical World 106, 1, 2012, 51-74 
Laehn 2013: T. R. Laehn, Pliny's Defense of Empire (New York 2013)

Lao 2011: E. Lao, Luxury and the Creation of a Good Consumer, in: R. K. Gibson - R. Morello (eds.), Pliny the Elder. Themes and Contexts (Leiden 2011) 35-56

Moussy 1966: C. Moussy, Gratia et sa famille (Paris 1966)

Murphy 2004: T. Murphy, Pliny the Elder's Natural History. The Empire in the Encyclopedia (Oxford 2004)

Naas 2002: V. Naas, Le projet encyclopédique de Pline l'Ancien (Rome 2002)

Naas 2006: V. Naas, Omnia ergo meliora fuere, cum minor copia (Pline l'Ancien, $N H, X X X V, 50)$. Matières et couleurs au service d'un discours moral dans la minéralogie de Pline l'Ancien, in: A. Rouveret - S. Dubel - V. Naas (eds.), Couleurs et matières dans l'antiquité. Textes, techniques et pratiques (Paris 2006) 201-211

Naas 2012: V. Naas, Anecdote et théorie de l'art chez Pline l'Ancien, in: E. Hénin - F. Lelercle - L. Wajeman (eds.), La théorie subreptice. Les anecdotes dans la théorie de l'art (XVIe-XVIII siècles) (Turnhout 2012) 39-52

Papini 2020: M. Papini, Pretia and Auctoritas Rerum. Evaluation of Materials and Artefacts in Books 33-37, in: A. Anguissola - A. Grüner (eds.), The Nature of Art. Pliny the Elder on Materials (Turnhout 2020) 181-193

Platt 2016: V. Platt, The Artist as Anecdote. Creating Creators in Ancient Texts and Modern Art History, in: J. Haninck - R. Fletcher (eds.), Creative Lives in Classical Antiquity. Poets, Artists and Biography (Cambridge 2016) 274-304

Pollitt 1974: J. J. Pollitt, The Ancient View of Greek Art. Criticism, History, and Terminology (New Haven, CT 1974)

Robert 1995: R. Robert, Immensa potentia artis. Prestige et statut des œuvres d'art à Rome à la fin de la République et au début de l'Empire, RA 1995, 291-305

Rouveret 1996: A. Rouveret, De l'artisan à l'artiste. Quelques 'topoi' des biographies antiques, in: M. Waschek (ed.), Les 'Vies' d'artistes. Actes du colloque international organisé par le Service culturel du Musée du Louvre (Paris 1996) 25-40

Sansone 1993: D. Sansone, Nero’s Final Hours, IllinCISt 18, 1993, 179-189

Wallace-Hadrill 1990: A. Wallace-Hadrill, Pliny the Elder and Man's Unnatural History, GaR 37, 1, 1990, 80-96 